\title{
TELEPEK ÉS EMBEREK \\ EGY DESZEGREGÁCIÓS PROGRAM MEGVALÓSÍTÁSÁNAK FÉLIDEI VIZSGÁLATA
}

\section{Szerzők:}

Kocsis Péter Csaba

Debreceni Egyetem (Magyarország)

\author{
Lektorok: \\ Soós Zsolt (PhD) \\ Debreceni Egyetem (Magyarország) \\ Trencsényi László (PhD) \\ Magyar Pedagógiai Társaság (Magyarország)
}

Első szerző e-mail címe:

kocspet@gmail.com

...és további két anonim lektor

Kocsis Péter Csaba (2021). Telepek és emberek. Egy deszegregációs program megvalósításának félidei vizsgálata. Különleges Bánásmód, 7. (2). 57-76. DOI 10.18458/KB.2021.2.57

\begin{abstract}
Absztrakt
A szegregált élethelyzetek felszámolását célzó programok az utóbbi két évtizedben ismét megjelentek a hazai integrációs gyakorlatban. Az úgynevezett „telepes programok” célja a társadalmi integráció és a lakhatási feltételek javítását célzó beavatkozások komplex megvalósítása, ennek során kiemelkedő szerepe van a szociális munkának. Tanulmányunkban egy jelenleg is futó integrációs program szociális munkásainak, valamint az egyik érintett szegregátum lakóinak felmérését végeztük el. A kutatás egyik kérdése a szociális munkával kapcsolatos tapasztalatok, az azt nehezító folyamatok beazonosítása volt, míg a célcsoport körében végzett felmérés a programban lévő elemek kihasználtságának, a csoportok közötti kapcsolatok jellemzőinek a vizsgálata volt. Jelenleg az országban közel száz településen zajlik hasonló program, ennek mentén vizsgáljuk a programok kialakulásának szakpolitikai hátterét, a szociális munkát szabályozó elő́rások változását, valamint a terepen dolgozó szakemberek és az érintett célcsoportvéleményét.
\end{abstract}

Kulcsszavak: roma integráció, telepes programok, szociális munka

Diszciplina: szociológia, szociálpedagógia

\begin{abstract}
SETTLEMENTS AND PEOPLE MID-TERM INVESTIGATION OF THE IMPLEMENTATION OF A DESEGREGATION PROGRAM

Programs aimed to eliminate segregated life conditions have appeared again in domestic integration practice in the last two decades. The goal of "Roma settlement programs" is the implementation of complex interventions improving social integration and housing conditions in communities, and social
\end{abstract}


work has an important role in this process. We will examine in our study the relevance of social work in an ongoing integration program in the framework of a survey that questioned social workers and residents of the segregates. The research focuses on two aspects of the programs. First, the social workers' experiences will be examined about their work and processes that complicate it, and secondly, a survey conducted among the target group will investigate the utilization of the elements in the program and the characteristics of the relations between the target groups. Finally, the policy background of the programs, changes in the regulations of social work, and opinions of the professionals and target groups will be introduced compared similar programs in nearly a hundred settlements in the country.

Keywords: roma integration, settlement program, social work

Disciplines: sociology, social pedagogy

A szegregált településrészek jelenléte, az ott jelentkező problémák komplexitása a mai lokális közösségek egyik jelentős problémája, amely nem csupán az ott élőkre, hanem a teljes település lakosságára is kihatással lehet. A probléma nem újkeletú, a roma csoportok hátrányos helyzetére az 1960-as évektól figyeltek a döntéshozók, bár a romák körében tapasztalható problémákat egyértelmúen szociális gondként kezelték, s mint ilyet nem vették figyelembe ennek etnikai vonatkozásait. A teendők az egyes szakpolitikai ágazatokban egyértelmúen kirajzolódtak, ilyen volt például az oktatás, vagy a lakhatás kérdése. Utóbbi esetében külön programok indultak el már az 1960-as évek végétől, majd különböző támogatási keretek között eltérő intenzitással, de jelen voltak a szakpolitikai beavatkozások között. A roma integráció kérdése a rendszerváltás, majd még inkább az európai uniós csatlakozás előtt időszakban vált igazán fontossá, ezért szakpolitikai programok kerültek megfogalmazásra és megvalósításra (Mezey, 1986). Ennek a legújabb változata a Roma Integráció Évtizede Program 2005-2015 (RIÉP, 2007) és az ezt követő Nemzeti Társadalmi Felzárkózási Stratégia 20112020 (MNTFS I., 2011), valamint ezek felülvizsgálatai. Az integrációs programok egyik fó területe a telepeken élők élethelyzetének javítása volt, erre külön célzott programokat hoztak létre és valósítottak meg, immár civil szervezetek és települési önkormányzatok. E programokat a pályázati megvalósitás szemszögéből többen vizsgálták (vö. Farkas, 2018; Kocsis, 2014; Petrovácz, Somogyi és Teller, 2010; Szalóky, 2015; Teller 2006)

Tanulmányunkban az eddigi gyakorlattól eltérően, az elvárt szociális munkával kapcsolatban kívántunk egy rövid felmérést végezni a szociális munkások körében. A programban érintettek egyéni fejlesztése a programok kötelezően elvárt alapvető tevékenysége, ezért ennek mentén vizsgáltuk azt, hogy a megvalósítás során milyen nehézséget látnak a szociális munkát végző szakemberek. A kutatás másik kérdése, hogy az érintett lakosság, a szegregátumban élő romák miként értékelik a programot. A kutatás az eddigi gyakorlattól eltérően, egy „félidei" vizsgálat a program megvalósításáról. A kutatás alapvetően félig strukturált interjúk felvételével (Babbie, 1996) készült. A programban hat szociális munkás látta el a feladatokat, őket fókuszcsoportos interjú keretében kérdeztük, míg a program által érintett embereket a legkedvezőtlenebb szegregátum esetében kérdeztük meg, amely indoka az volt, hogy képet kívántunk kapni arról is, hogy a falusi 
csoportoktól (roma és nem roma csoporttól egyaránt) lévő társadalmi távolságuk miként alakult a program hatására. A felmérés Szabó-Fábián Katalin közösségi és civil fejlesztő szakember segítette.

A tanulmány röviden áttekinti a hazai integrációs célkitűzések főbb állomásait, azok tartalmát, a 2005 utáni telepes programok főbb tartalmi elemeit. A kutatás helyszínét röviden, a KSH adatai, valamint egyéb helyi dokumentumok alapján mutatjuk be. A kutatás értelmezését segíti a telepes programok és a szociális munkával kapcsolatos pályázati elvárások változásának rövid áttekintése, majd ismertetjük a szociális munkára vonatkozó, valamint a célcsoporti felmérés eredményeit.

\section{Programok a szegregált élethelyzet ellen}

A hazai cigányság élethelyzetének vizsgálata az utóbbi évtizedekben egyre szélesebb szakirodalommal rendelkezik. Röviden érdemes azonban áttekinteni, hogy a hazai cigányság helyzetére és ezen belül is a telepek összetett problémájának kezelésére milyen szakpolitikai elképzelések születtek.

Az első jelentős kormányzati intézkedés az 1961es MSZMP KB Politikai Bizottságának határozata volt, amely a cigányság általános helyzetével foglalkozott, érintette a kulturális, munkaerő-piaci jellemzőket, de emellett kiemelten foglalkozott a Magyarországi telepek kérdésével is. A magyarországi cigányság létszámát 200 ezer főre becsülték, ezen belül rögzítették, hogy a cigány lakosságon belül megállapított három kategóriában mekkora a cigány lakosság becsült aránya. Ennek alapján beilleszkedett csoportba sorolták a cigányság kb. 30\%-át, beilleszkedésben lévő csoportba soroltak további kb. 30\%-ot, míg a be nem illeszkedett csoportba tartozott amely a definíciójuk szerint félig letelepedett és vándor közösségeket jelentett a cigányság kb. 40\%-a (Mezey, 1986). A határozat a cigányság problémái között említi a munkaerő-piaci helyzetüket, amely szerint csupán a cigányság közel 33\%a rendelkezik állandó munkával, 32\%-a alkalmi munkával, míg 35\%-a egyáltalán nem dolgozik. Az iskolai végzettséggel kapcsolatban a határozat rögzíti a romákra jellemzô alacsony iskolai végzettséget, bár erre vonatkozóan számszerú adatokat nem említ, csupán a „többségük” megjelölést alkalmazza.

Tanulmányunk szempontjából fontosabb, hogy a magyarországi cigánytelepek számát is megbecsüli a dokumentum, a felmérések szerint ekkor 2100 telep volt az országban. Ezek jellemzően a településtôl távol, nehezen megközelíthető helyeken álltak, az épületek sokszor lakhatásra alkalmatlanok voltak. A foglalkoztatás terén is voltak anomáliák, hiszen a nagyfoglalkoztatók - jellemzően TSz-ek és állami gazdaságok - elzárkóztak a cigányok alkalmazásától. A korabeli összefoglaló a cigányság problémáit reálisan azonosította be, még akkor is, ha sok adata csupán becsléseken, a megyei pártbizottságok munkatársainak becslésén alapult (Kocsis, 2019). A helyzetfeltárást programalkotás követte, a célok között szerepelt a romák oktatásba vonása, amely elsősorban az általános iskola elvégzését jelentette, a foglalkoztatás növelése, amely érdekében a nagyfoglalkoztatóktól várták el az alacsony képzettségű emberek foglalkoztatását, az egészségügyi helyzetük javítása, valamint a lakhatási feltételek javítása is.

Utóbbi terület kiemelkedő volt a határozatban és a korabeli dokumentumokban is, amely eredményeként több beavatkozás született a cigányság lakhatási körülményeinek javítására. A kérdés kezelésére született meg a 2014/1964. (V.4.) és 2047/1967. Kormányhatározat, amely a cigány telepek megszüntetését az ötéves tervek ütemezésében kívánta megoldani. Az első ilyen tervezet 1965-ben országszerte 800 családi ház megépítését túzte ki célul (Hajnáczky, 2015), amely körül az anomáliák már a korai időszakban megjelentek. A lakásépítési konstrukció, bár központi akaratra és költségvetési támogatás mellett valósult meg, a családok részérôl bizonyos önerőt $(10 \%)$ is megkövetelt (MajtényiMajtényi, 2012), ennek biztosítása sok család ese- 
tében lehetetlen volt. A lakókörülmények a telepfelszámolási program eredményeként javultak, de a térbeli szegregációt jellemzően nem oldották meg, sôt, a beavatkozások hatására új telepek jöttek létre (Kállai-Törzsök, 2006). Az említett határozatok mentén a lakhatási helyzet javítása ugyan megkezdődött, és bár az 1960-as, 1970-es években a beavatkozások központi irányítás mellett történtek, elvárt eredményeit a korszak bürokratái teljesíthetetlennek tartották, ahogyan fogalmaztak: „a községi tanácsok nem látják a széttelepités perspektiváit' (Majtényi-Majtényi, 2012, 66.o.), vagyis joggal feltételezhetjük, hogy a helyi irányítók a rendelkezésre álló eszközökkel lassították, esetenként megakadályozták az integrációs folyamatokat, amely vélhetôen - a mai tapasztalatokhoz hasonlóan - a nem roma társadalom vélt, vagy valós elégedetlenségén alapultak.

A rendszerváltás utáni programok közül még két nagyobb volumenú beavatkozást említünk meg, jelezve egyúttal azt is, hogy ezek mellett az 1990 után létrehozott Cigány Koordinációs Tanács (1995), Cigányügyi Tárcaközi Bizottság (1999), majd később a Roma Integrációs Tanács (2007), Roma Irányító és Monitoring Bizottság (2007), a Társadalmi Felzárkózási és Cigányügyi Tárcaközi Bizottság (2011), valamint a Roma Koordinációs Tanács (2011) számos fontos kérdést tárgyalt, utóbbiakhoz már a jelenleg meglévő stratégiai tervek is köthetők.

A korábbi kormányzati elképzelések folytatásaként, de konkrétabb beavatkozások mentén született meg a Roma Integráció Évtizede Program 2005-2015 és később, ezen dokumentum tartalmi elemeit átvéve a Nemzeti Társadalmi Felzárkózási Stratégia I. is, és újabb elemekkel kiegészülve megtaláljuk a Magyar Nemzeti Felzárkózási Stratégia II., valamint a Magyar Nemzeti Felzárkózási Stratégia 2030 célkitűzései között is.

A stratégiák mindegyike jellemzően hat területen fogalmazott meg szükséges beavatkozásokat, ezek között találjuk az oktatás kérdését, amely abból a jellemzőből indul ki, hogy a romák iskolai végzettsége elmarad a nem roma populáció jellemzőitől; a foglalkoztatás területét, amely esetében egyértelmú összefüggés mutatható ki az iskolai végzettséggel; a lakhatás kérdéskörét, amely a telepek és szegregátumok jelenlétét és az ott tapasztalható problémákat rögzíti; az egészségügyet, amely alapvetô állitása, hogy a romák egészségügyi helyzete lényegesen rosszabb, mint a nem romáké; az egyenlő bánásmód kérdését, amely a mindennapi életben tapasztalható és jogi eszközökkel értelmezhető diszkriminációs folyamatokat említi; valamint a kultúra, média, sport területét, amely rendszerint az integrációs eszköztárban az egyik olyan elem, amely - az elképzelések szerint - a romák és nem romák közötti távolságot csökkenteni tudja. (RIÉP, 2006; MNTFS I., 2011; MNTFS II., 2014; MNTFS 2030, 2020)

\section{Telepes programok}

A telepfelszámolási programok, vagy később inkább teleprehabilitációs programok legújabb megvalósítása a RIÉP 2005-2015 elfogadása után indult el. Több pályázati konstrukció biztosított forrást a településeken megvalósítandó humán és infrastrukturális fejlesztésekre. (A teljesség igénye nélkül ide tartoztak: 2007 és 2013 között a TÁMOP-5.3.6 és TIOP-3.2.3, a 2014-2020 időszakban megjelenő EFOP-1.6.2 és EFOP-2.4.1. Megjegyzendô, hogy utóbbi ciklusban a megyei jogú városoknak, a városi jogállású településeknek és a nem városi jogállású településeknek különkülön pályázati forrás állt rendelkezésre, hasonló szakpolitikai célkitűzésekkel.)

A lokális térben az etnikailag meghatározott településrészeket a helyi tudás minden esetben be tudja azonosítani. A telepek léte nem csupán az etnikai szegregáció térbeli leképeződése, hanem szociális szempontból halmozottan jelennek meg a problémák, az anyagi depriváció, sok esetben a mélyszegénység, az alacsony iskolai végzettség, 
egészségügyi, szociális, munkavállalási problémák, amelyek sokszor a lakókörnyezet és a lakás elégtelensége egészít ki. Ez a kedvezőtlen helyzet ahogyan arra a történeti példán keresztül rámutattunk - nem újkeletú a településeken, sőt az 1970es évektől kezdődően folyamatosan újratermelődtek az ilyen településrészek, valamint a kapcsolódó problémák is folyamatosan jelen vannak. Az uniós célkitűzések között a szegénység felszámolása, az iskolai lemorzsolódás csökkentése, a foglalkoztatottság növelése - hogy csak néhány, a témánk szempontjából fontosabb területet emeljünk ki - uniós ciklusokon átívelő stratégiai beavatkozást jelent (Európa 2020, 2010). A szakpolitikai célkitűzések között a rendszerváltás utáni évektôl folyamatosan megjelenik annak az igénye, hogy a szegregált élethelyzetben élők megsegítésére célzott programokat hozzanak létre. Ezt a célt szolgálták a különböző szociálpolitikai beavatkozások, mint például a kedvezményes hitelek, a szociálpolitikai kedvezmények, amelyek a lakhatás infrastrukturális feltételeit némileg javították. A térbeli szegregáció azonban nem tűnt el, sőt, a számok azt mutatják, hogy tovább erősödött. A Kemény-féle 1971-es kutatást alapul véve látható volt, hogy a korai telepfelszámolási programok csökkentették a telepen élők arányát, hiszen 1964 ben 49 ezer telepi házban 222 ezer személyt írtak össze, 1984-ben 6277 telepi házban már csak 42 ezer személyt. Az 1993-es felmérések idején a cigányok 13,7\%-a, mintegy 60 ezer ember élt telepeken, a 2003-as összeírás szerint 36 ezer fó élt ilyen körülmények között (Kemény, Janky és Lengyel, 2004; Farkas, 2018). Ehhez képest a 2010-es felmérések jelentős emelkedést mutattak, hiszen a telepeken élők számát mintegy 300 ezer emberre becsülik (Domokos, 2010).

Az emelkedést több folyamat együttes hatásának tudhatjuk be, többek között ide sorolhatjuk, hogy a rendszerváltás utáni szociálpolitikai kedvezmények ösztönözték az újabb lakásépítéseket, ennek hatására a települések perifériáján elérhető, olykor az önkormányzatok által kedvezményesen, vagy ingyenesen biztosított építési telkeket a roma családok kapták meg. A foglalkoztatás átalakulásával a korábbi ipari központok jelentős része felbomlott, ennek hatására az egykori munkásnegyedek lakossága kicserélődött, amely szintén elindított szegregációs mechanizmusokat, ilyen például Miskolc vagy Ózd példája. Ezek mellett azonban az általános demográfiai trendek is hozhattak ilyen változásokat, az idősödő falvak lakossága szintén változott, kicserélődött.

A szegregátum fogalmának használata a 2005 utáni időszakban vált egyre inkább elterjedtté, amikor a RIÉP 2005-2015 elfogadása után az első programok elindultak. Ezzel párhuzamosan fontossá vált, hogy a szegregátumokat objektív mutatók mentén lehessen lehatárolni, így meghatározásra került a szegregátum objektivizált fogalma. (Net1) Ebben az alábbi szempontok érvényesülnek: 1 . az adott területen élők legfeljebb általános iskolai végzettséggel rendelkeznek; 2. rendszeres munkajövedelem hiánya jellemző az ott élókre; 3. legalább 50 fős népesség egy adott településrészen, amelyre a 2 szempont érvényesül; 4. az adott, térbelileg körülhatárolható területen a 1. és 2. szempont legalább 50\%-ban érvényesül. A népszámlálási adatok tükrében a KSH állította eló azokat a települési kartogramokat, amelyek a kormányrendeletben meghatározottak szerint település térszerkezetén belül jelezték a szegregátumokat és a szegregációval veszélyeztetett területeket. (A százalékos arányokat a 314/2012. (XI. 8.) a településfejlesztési koncepcióról, az integrált településfejlesztési stratégiáról és a településrendezési eszközökről, valamint egyes településrendezési sajátos jogintézményekről szóló Kormányrendelet módosította, a településnagyság szerint határozta meg így az 50\%-os határ 2000 fơnél kisebb településeken maradt használatos, míg ennél nagyobb településeknél 20 és 35\% között változik.)

A szegregátum meghatározásából kiindulva a telepek alapvetően két módon szüntethetőek meg: 
az egyik a telepek fizikai felszámolása és az ott élők térbeli mobilizációja, természetesen annak a veszélyével, hogy újabb szegregátumok jönnek létre, ahogyan erre volt példa a magyarországi gyakorlatban; a másik, hogy a szegregátumokban élők helyzetét alapvetően befolyásoló tényezőket módosítjuk, vagyis az általános iskolai végzettségnél magasabb iskolai végzettséget szereznek, vagy állandó munkajövedelemmel rendelkeznek az ott élők. Utóbbi folyamatban a szociális munkának, a segítő attitűdnek kiemelkedően fontos szerepe van az érintettek életének számos vonatkozásában (L. Ritók, 2017).

\section{A település rövid ismertetése}

Pocsaj Hajdú-Bihar megyében, annak délkeleti részén található. A település periférikus jellegét földrajzilag az országhatár közelsége jelzi, a román határtól légvonalban mindössze hat kilométerre van. A településen tervezték kishatárátkelő létesítését is, ennek kiépítése megtörtént, de átadása még várat magára. A településen a rendszerváltás előtti időszakban a mezőgazdasági tevékenység volt jellemző, két szövetkezet biztosította a megélhetést a helyieknek, valamint a környező városok, Berettyóújfalu, Derecske és a megyeszékhely, Debrecen biztosított az iparban és a szolgáltató szektorban elhelyezkedést.

A rendszerváltás utáni időszak átalakította a foglalkoztatási szerkezetet, a lakóhelyről történő ingázás, valamint a lakóhelytől távoli munkavállalás - amely sok romát érintett a településen visszaszorult, és a helyi foglalkoztatók is megszűntek, privatizálására kerültek. Ennek eredményeként sokan elveszítették megélhetésüket, a privatizált és modernizált gazdaságok lényegesen kevesebb képzetlen munkaerőt igényeltek. A nagygazdálkodók mellett kisebb családi gazdaságok alakultak ki, valamint a helyi közintézmények biztosí- tottak foglalkoztatást, ide sorolhatjuk az óvodát, az általános iskolát, valamint az önkormányzatot.

A megélhetést a helyi képzetlen munkaerő számára elsősorban a közhasznú munka, majd a közfog-lalkoztatási rendszer bevezetése biztosítja, ez nagy arányban érinti a helyi roma közösség tagjait. Ez rendszerint szezonális munkavállalással, a környező településen történő tormatermesztéshez kapcsoló-dó napszámos munkával egészül ki. (Közösségi Beavatkozási Terv, 2017)

A településen a demográfiai trendek az 1980-as évektől a népesség fogyását mutatják, a teljes lakosság 2011-ben 2725 volt, nagyságrendileg ma is ez a létszám jellemző.

A település lakossága mindig vegyes volt, a magyarok mellett román, roma és néhány fős német nemzetiség jellemezte az itt élő közösséget. Németnek 2011-ben 7 fô vallotta magát, nagyobb volt a román nemzetiség, 124 fővel, valamint a roma közösség 569 fövel (KSH, 2011).

A román és a roma kisebbség nemzetiségi önkormányzatot is létrehozott. A roma kisebbség arányáról jellemzően magasabb számot becsülnek a helyiek, a köznevelési intézményekben egyértelműen tapasztalható a roma gyerekek nagyarányú jelenléte, többségében roma gyerekek járnak a helyi általános iskolába. Ennek okai között a nem roma gyerekek szomszédos településre történő elhordása, valamint a demográfiai trendek együttesen állnak. A nem roma fiatalok jelentős része már nem a településen képzeli el jövőjét, ezért Debrecenbe, de Budapestre és külföldre is sokan elköltöznek, valamint a roma közösséget magasabb gyermekvállalási hajlandóság jellemzi. E három ok együttesen okozza a köznevelési intézményekben tapasztalható arányokat.

A településen a roma közösség az utóbbi évtizedekben folyamatosan jelen volt. Erre vonatkozó helytörténeti adatok nem állnak rendelkezésre, de a helyi emlékezet ma még beazonosítja, hogy a romák lakhelye egykor a település szélén, a temető mellett volt, és az 1960-as évek végétől indult meg 
a betelepülés a falu egy másik részébe, az úgynevezett Apáti telepre.

Ez a településrész korábban azoknak a földműveseknek szolgált lakóhelyül, akik Széchenyi Ágost birtokos cselédségét képezték. Az itt élő népesség más területre történő elköltözése után jelentek meg a roma családok az Apáti telepen, amely ma a település egyik legrosszabb helyzetben lévő szegregátuma.

A településen összesen négy szegregátum található, elhelyezkedésüket tekintve mind a négy a település perifériáján van. Nagyságuk változó, kb. 70-80 főtől közel 350 főig terjed a népességük. A település egészén a 0-14 évesek korosztályi megoszlása 23\%-os volt 2011-ben, ezeken a területeken a 25,7 és 44,7\% között változott, amely azóta tovább emelkedett. Az idősebb, 60 év feletti korosztály esetében fordított a helyzet, a település egészét tekintve 19,6\%-os volt, míg a szegregátumokban 17,6 és 7,7\% között változott.

A település egészét tekintve az iskolai végzettség vonatkozó-sában is sajátos képet kapunk, a legfeljebb 8 osztályt végzettek aránya települési szinten $43 \%$, ez a szegregátumok lakossága esetén 59,5 és $87,5 \%$ között változott, amely egyértelmúen jelzi a roma populáció alacsony iskolai végzettségét a településen. Ugyancsak ezt a trendet követi a rendszeres munkajövedelem hiánya is, amely a település egé-szét tekintve 54,8\%-os volt, a szegregátumok mindegyikében magasabb, 61,9 és 90\% között változott $\mathrm{az}$ arány. $\mathrm{Az}$ alacsony komfortfokozatú lakások aránya esetében szintén a szegregátumok kedvezőtlenebb helyzetét figyelhetjük meg: a települési átlag 27,4\%, míg a szegregátumok 32,1 és 81,1\% között változnak. A 2011-es népszámlálások adataiból előállított adatsorok egyértelmúen alátámasztják a hazai cigányság kedvezőtlen helyzetének tendenciáit.

Pocsajon is az alacsony iskolai végzettség, a munkajövedelem hiánya, a lakások fejletlen infrastruktúrája jellemzi a roma közösség életét. A 2011es adatok természetesen változtak, a településen jól érzékelhető, hogy a szociálpolitikai kedvezmények hatására (CSOK, falusi CSOK) a roma családok is költöznek a településen belül, de ezzel együtt az is tapasztalható, hogy a szegregátumokból kiköltözők helyére újabb családok érkeznek, így azok elnéptelenedése, felszámolása rövid távon nem várható.

\section{A telepes programok és a szociális munka}

A telepfelszámolási programok 2005 után a szegregátumok problémáinak komplex jellegét hangsúlyozták, ezzel kijelölték a beavatkozási irányokat is. A következőkben vázlatosan az egyes idôszakok szociális munkára vonatkozó sajátosságait tekintjük át.

A 2005-2010 közötti időszakban a szociális munkához kapcsolódó elvárások jellemzően a célcsoport és a meglévô szolgáltatók közötti közvetítésre, a szolgáltatások elérésére szorítkoztak, az érintettek ügyintézésében, valamint a programban való részvétel során nyújtottak támogatást. A szociális munka beavatkozásának alapvető logikája az volt, hogy a szolgáltatások legalább a program megvalósítása során eljussanak az érintettekhez, és a kialakult kapcsolat, a segítői feladatok ellátása biztosított legyen. A szegregátumban élők egyéni fejlesztése is megtörtént, ennek a folyamata nem volt sztenderdizálva, az adott szociális munkásra és a településen lévô szolgáltatókra volt bízva. A fó irány az ágazati szereplők és a kliensek összekötése volt, a program során azonban egy személyre szabott segítés is biztosított volt. A szegregátumban élő családok közül a legrosszabb helyzetben lévők lakhatási helyzetén is igyekezett segíteni a program, a források korlátozottsága miatt ez nem terjedt ki mindenkire, amelyből a közösségen belül alakultak ki konfliktusok, így a szociális munkásnak mediátori feladatai is adódtak.

A 2007-2013 közötti időszakban megvalósított TÁMOP-5.3.6 kódjelû pályázati kírásában megfogalmazott szakmai elvárások szintén a komplex humán szolgáltatások biztositását követelték meg. 
A programkiírásban megfogalmazott részcélok szerint elvárás, hogy javuljon a szolgáltatásokhoz való hozzáférés (szociális, közösségi, oktatási, képzési, egészségügyi és munkaerô-piaci területen egyaránt); javuljon a bevontak képzettségi szintje; növekedjen azon személyek száma, akik bekapcsolódnak az egyes részprogramokba; növekedjen a foglalkoztatásba kerülők száma; növekedjen a szegregátumból óvodába bekerülő gyerekek száma; javuljanak az iskoláskorúak előrehaladási esélyei és szabadidő eltöltésének lehetőségei. Az integrációs programok megkövetelték a lokális környezet felmérését és a jelentkező problémákra reflektáló programok megvalósítását. Így arra is lehetőség nyilt, hogy egyéb intézmények feladatait is elláthassák a program munkatársai, így pl. az iskolai napközi helyett tanoda jellegú programok szervezését, egyéb szabadidős tevékenységet, de szűrések, célcsoporti kirándulások megvalósítása is a programok között lehetett, vagyis, ha a tervezett beavatkozás megalapozott volt, akkor a döntéshozó engedte az adott fejlesztés, szolgáltatás megvalósítását. A szociális munkások vagy esetmenedzserek alkalmazása kötelező elem volt, ezzel kapcsolatban elvárás a szociális területen szerzett végzettség, két év, az adott célcsoporttal szerzett, egyéni esetkezelésen alapuló szakmai gyakorlat, amelyet az alkalmazás feltételeként bizonyítani kellett. A kiirás szakmai törekvése magas színvonalú szociális munka biztosítása volt (Net2), ugyanakkor már látható volt az is, hogy a területen lévő szakemberek között jelentős hiány mutatkozott, így kérdéses volt a segítő munka biztosítása.

A harmadik szakaszt a 2014-2020 időszak EFOPos programjai jelentik. Ezek közül még jónéhány jelenleg is megvalósítás alatt áll. A szakmai célkitűzések a korábbi időszakhoz képest jelentősen nem változtak, megőrizték a komplex szemléletüket a tervezésnél és a megvalósításnál egyaránt, így jelentôs maradt a szociális megsegités, az oktatás támogatása, a felnőttképzések szervezése, egészségügyi, közösségfejlesztési és munkaerôpiaci programok. Új és hangsúlyos elemként a helyi önszerveződések támogatása jelent meg, ennek eredménymutatója helyi roma civil szervezetek létrejötte lenne.

A programhoz most már kötelező jelleggel kapcsolódott a lakhatási feltételeket javító infrastrukturális elem is, ez azonban a bevontak csupán egy kis részét, jellemzően a humán fejlesztési programba bevontak 20\%-át érintette. (Net3; Net4)

Az egymást követô programokban a szociális munkával szembeni elvárások folyamatosan növekedtek. A program sajátossága lett, hogy a Magyar Máltai Szeretetszolgálat által jegyzett "Jelenlét típusú" szociális munka módszertani elterjesztése megtörtént, ennek néhány jellemzőjét a későbbiekben ismertetjük. A másik jelentős változás, hogy a programban erősödött a dokumentációs teher, amely ugyan a segítő folyamat minden lépését nyomon követhetővé teszi, de a 15 féle dokumentum pontos és megfelelő kitöltése jelentős időráfordítást igényel. További változás volt, hogy a szociális munkások körét kibővítették, nem volt már elvárás a kétéves szakmai gyakorlat, szociális végzettség helyett több tucat egyéb, például pedagógusi, hittanári, népmúvelői stb. végzettség is megfelelő volt, valamint a maximum 15 fős kliensi kör 30 före bővült. (Net3) A programban résztvevő esetmenedzserek/szociális munkások számára 72 órás képzést szerveztek, amely a speciális területen és speciális nehézségekkel küzdő célcsoporthoz alkalmazkodó módszertan elsajátítását célozta.

A szociális munka jelentôsége a telepes programmok kapcsán a kezdetektől hangsúlyos, a szakmai sztenderdek kidolgozásra kerültek, ezzel párhuzamosan a programban szociális munkakörben alkalmazandók köre az ágazatban tapasztalható humanerőforrás-hiány miatt folyamatosan bővült, ahogyan az ellátható kliensek száma is emelkedett. 


\section{Módszertani sajátosságok}

A telepes programok sajátos módszertana lett a Magyar Máltai Szeretetszolgálat által "Jelenlét típusú szociális munka" névvel fémjelzett szakmai sztenderd. A szakmai hátteret a settlement típusú szociális munka biztosítja, amely a 19. századtól Angliában, az Egyesült Államokban és Európa több országában is jelen volt. Céljai között megtaláljuk a szociális helyzet enyhítését, az ismeretek bővítését, valamint képzési törekvéseket egyaránt (Soós, 2005; Hilscher, 1989). A Jelenlét programok (Jelenlét, é.n.) megközelítésének alapvetései között a hagyományos szociális munka ellátó és ellátott közötti lévő hierarchizált viszonyával való szakítás, a kölcsönös bizalomra épüló kapcsolatok kiépítése szükséges. Ez a megközelítés a szociális munka egyik lényeges etikai normája is, amely a klienssel való egyenrangú kapcsolatot követel meg (Net5). A Jelenlét programok alapvetô jellemzői között a közösség életében történő folyamatos jelenlétet, a komplexitást, a közösségi jelleget és a rehabilitációt emelik ki a szakemberek. Ezeket részletesebben vizsgálva arra a megállapításra juthatunk, hogy a jelenlét fizikai jelenlétet jelent a közösség életében, amely fizikailag is ott lévő irodát jelent. Ezt a telepes programokban az ún. szolgáltató pontok biztosítják, amelyek a szociális munkások ügyfélterei is egyben. A komplexitás több szakterületre történő együttes figyelmet jelent, így a szociális ellátásra, az oktatásra és képzésre, a foglalkoztatásra, a gazdaságfejlesztésre, az egészségügyre és a kultúrára együttesen koncentrál. A közösségi jelző a családok és a közösség aktivizálását, a meglévő belső erőforrások használatát, valamint az érintettek elköteleződését jelenti a programokban való részvételre, a rehabilitáció pedig az emberi méltóság visszaszerzését foglalja magában. A szociális munka elméleti alapjait és gyakorlatát áttekintve hasonló elméleti megközelítésekkel találkozhatunk. A 20. századi funkcionalista modell célrendszerében négy kiemelt célt említenek, ezek között szerepelnek: az egyén problémamegoldó és problé- makezelő képessége; az egyén és az ellátó rendszere közötti kapcsolat erősítése és biztosítása; az ellátó rendszerek hatékony és emberközpontú múködtetése; valamint a változó szociálpolitika pozitív irányú befolyásolása (Soós, 2018). A szociális munkában alkalmazott problémamegoldó modellek a Jelenlét típusúként nevezett szociális munkával átfedést mutatnak, mert mint módszert alkalmazzák azt. A feladatközpontú modellekben a fó célkitűzés a kliensek bevonása oly módon, hogy nem ad konkrét megoldási javaslatokat, amellyel a függőséget növelné, hanem a problémamegoldási folyamat részekre bontásával a kliens számára átláthatóvá, megérthetôvé teszi a folyamatot és lehetőséget biztosít, hogy lépésről-lépésre ő maga tudjon adekvát cselekéseket létrehozni (Soós, 2018). Bizonyos esetekben a krízisintervenciós modellek alkalmazása is adekvát válasz lehet, hiszen a szegregált körülmények között élők mentális állapota is gyakran sérül, egy segitési/fejlesztési folyamatban indokolt és szükséges lehet ennek alkalmazása, amely egyúttal azt is jelenti, hogy a szociális munkás más, az egészségügyi rendszerben dolgozó kollégájával is együttmúködik. E folyamat során a családdal való kapcsolattartás szintén fontos kritérium, hiszen a folyamatot a szociális szakember követi, kíséri. Végezetül, ha a rendszerszemléletű, családközpontú megközelítést áttekintjük, akkor láthatjuk azt is, hogy az 1980-as évektől a család szerepe és az erre irányuló fejlesztő munka felértékelődött, újragondolásra került. Ennek a megközelítésnek az egyik állítása éppen az volt, hogy a kliensek problémái abból adódnak, hogy a meglévő erőforrásokhoz nem jutnak hozzá, ezért a szociális munka arra irányul, hogy a család múködését javító segítséget és az erőforrásokhoz való hozzáférést egyaránt kezelje (Soós, 2018).

A szociális munka alapvető kérdése, hogy az egyes programszerú beavatkozások után - melyek rendszerint néhány évig tartanak - hogyan válnak fenntarthatóvá az elért eredmények. Ehhez vélhetően - további források szükségessége az 
alapvetô válaszunk, de ennek híján a fenntarthatóság irányába tett erőfeszítések is alkalmasak lehetnek. Ennek alapjait az ökologikus megközelítés segítheti, amely lényege, hogy az ellátás folyamatában az egyének aktivizálása megtörténjen akár az empowerment módszerével (Vercseg, 2011; Herpainé, 2011; Soós, 2018), akár a csoportokkal vagy közösséggel végzett szociális munka módszereivel. Ezek elterjedése még várat magára, hiszen a magyarországi szociális munkát az önkéntességen alapuló esetközpontúság jellemzi, amelyet tovább nehezített a szakemberekre jutó esetek magas száma, így sok esetben a kliens-győzködő magatartás alakult ki, valamint a szociális problémákkal küszködők helyzetének gyors és olcsó megoldását várta a rendszer. (Jász, 2011)

\section{A szociális munkások tapasztalatai}

A szociális munka fontossága az integrációs programok szempontjából elengedhetetlen. Kutatásunkban a Pocsajon található négy szegregátum közül kettôt érintett az integrációs program, a felmérésben a szociális munkások mindegyikét megkérdeztük tapasztalataikról, valamint a legrosszabb állapotban lévő szegregátum, az Apáti telep lakosai között végeztünk felmérést, utóbbi eredményeit a következő fejezet tartalmazza.

A programban dolgozó szociális munkások tapasztalatainak felmérésére fókuszcsoportos interjú keretein belül került sor. A hat szakember közül egy fő volt férfi, mindannyian több éves, minimum öt éves gyakorlattal rendelkeznek. A kérdések egy része a szociális munka tárgyi feltételeit vizsgálta, így a foglalkoztatás módját, a kapcsolódó dokumentáció megítélését, a feladathoz kapcsolódó időkeretek tapasztalatait. A másik kérdéscsoport a célcsoporttal való munkájukra vonatkozott, a kapcsolatépítés módjára, együttmúködési mintákra, ezen kapcsolatok minőségére, valamint a célcsoport motiválásának gyakorlatára. Az interjú célja, hogy a célcsoporttal kapcsolatos tapasztalatok, valamint a felmerülő problémák beazonosításra kerüljenek, s közvetve értékeljék az addig elvégzett munka eredményeit is. Az interjúban a projektben dolgozó hat szociális munkás vett részt, akik heti 20 órában látják el feladataikat.

A szociális munkások időbeosztásával kapcsolatban elmondták, hogy a heti 20 órás munkavégzés gyakorlatilag azt eredményezi, hogy a munkaidôn túl tudják a szükséges feladatokat elvégezni. Ez alól három, a helyi ellátórendszerben dolgozó munkatárs a kivétel, akik a napi munkájuk során esetenként egyéb ügyekből kifolyólag találkoznak a kliensekkel, így a programhoz kapcsolódó tájékoztatási, fejlesztési feladatokat részben ekkor is el tudják látni.

A másik három ún. „külsős” munkatárs közül egy a helyi iskolában dolgozik, így az ő feladat-végzése a munkaidô utáni időszakra korlátozódik, ahogyan a másik két munkatárs is munkaidő után, valamint hétvégén tudja ellátni a feladatait.

A célcsoport vonatkozásában közös problémaként merült fel, hogy a fellelhetőségük sokszor nehézkes, hiszen a környéken és távolabbi településeken is vállalnak alkalmi munkát, ennek következménye, hogy a látogatás időpontjában nem minden esetben vannak otthon, ez további megkereséseket tesz szükségessé. A kliensekkel való kapcsolatfelvétel természetes tere lenne az esetenként hétvégén szervezett programok helyszíne, azonban ezeken a szociális munkások szórványosan vesznek részt, a saját családi életük akadályozza ebben őket. Megemlítették problémaként, hogy sokszor előfordul az, hogy előre egyeztetett időpontban keresik fel az „ügyfelet”, azonban az ígéretek ellenére nem tartózkodnak otthon, amely nehezíti a munkát. A munka dokumentációs terhe miatt ez lassítja a határidők teljesítését.

A szociális munkások adminisztrációs feladatait nagyon megterhelónek tartják, amely a fejlesztési feladatoktól veszi el az időt. Folyamatos feladatként jelentkezik az egyéni fejlesztési tervek vezetése, az ehhez kapcsolódó családlátogatások dokumentá- 
ciója, valamint a legtöbb esetben a családi fejlesztési tervek dokumentációja. Mindkét dokumentum esetében szükséges a megvalósulás háromhavonkénti felülvizsgálata, amely folyamatos dokumentációs kényszert jelent számukra. A napi munkavégzést sok esetben újabb dokumentációs teher egészíti ki, amelyet az Irányító Hatóság által meghatározott adatszolgáltatási kötelezettség, és különböző célcsoporti nyilatkozatok felvétele nehezít.

A célcsoport motivációjának és együttműködési gyakorlatának rapszodikus változásáról számoltak be a szociális munkások. A kezdeti időszakban nagyobb volt az együttmúködési hajlandóság, amelyet a programmal kapcsolatos elvárásoknak tulajdonítanak. A vélemények a szociális munkások között megoszlottak arra vonatkozóan, hogy ebben a változásban milyen szerepe van a segitő személyének. Két tipikus válasz fogalmazódott meg: az egyik szerint az együttmúködési hajlandóság és a motiváció csökkenése a célcsoport hibájára vezethető vissza, gyakorlatilag ,nem akarják csinálni azt, amit a szakember mond nekik", valamint „csak akkor érdekli öket, ha pénzt kapnak érte". E csoport megfogalmazta azt is, hogy az a lényeg, akkor motiváltak, ha „valamit kapnak, mindegy, hogy mit, pénzt vagy egyéb dolgot, a lényeg, hogy kapjanak". A másik álláspontban - amely talán jobban tükrözi a szociális munka lényegét - a segítő személyével kapcsolatban fogalmaztak meg kritikát. „Én nem tudom, nekem nincs problémám velïk, pedig az apátisok tartoznak. hozzám, nem mindegy, hogy az ember bogyan szól bozzájuk, és talán fontos az is, hogy kint vagyok. köröttiilk és el tudunk beszélgetni”. A gondolkodás rámutat arra is, hogy a telepes programhoz kapcsolódó szociális munka túlmutat a megszokott családsegítési gyakorlaton. A „hivatali szerepből” való kilépés mindenképp fontos eleme lehet a bizalmi kapcsolat kiépítésének. Bár a szociális munkát gyakran éri bírálat, hogy a '70-es évek gyakorlata még mindig fellelhetô, de egyéb esetleírásokból pontosan láthatjuk, hogy felkészült szociális munkásként a bizalmi viszony és a kliensek szemléletváltása elérhető. (Lásd pl. Soós, 2018; Csoba - Prókai, 2011) Az első álláspont okát vélhetően két tényezővel magyarázhatjuk: az egyik a Magyarországon meghonosodott szociális segítés nézeteinek tovább élése lehet, amely a kliensek szerepét az alá-fölérendeltségi viszonyban fogalmazza meg, s így nem alakul ki a partneri viszony; a másik vélhetően a hazai segélyezési, integrációs vagy legújabban felzárkózási törekvések során kialakult rossz gyakorlat, amely a célcsoport fontos megjegyeznünk, hogy célcsoport és így teljesítendő indikátor és nem pedig segítségre szoruló ember - aktivitásának növelését különböző „motivációs ajándékok" formájában érte el. Ezek megszüntetése, a „tenni akarás” a saját problémák megoldásában így komoly kihívásként jelentkezik, amelyet a fenti tényező́k gátolnak.

A célcsoport fejlesztésével kapcsolatos tapasztalatok is legalább két csoportba oszthatók. Az egyik megismételte a motivációval kapcsolatos álláspontot, amely a rövid távú „haszonszerzés” nézetét hangsúlyozta, például „addig érdekli öket, amig kapnak valamit', míg a másik álláspont arra hívta fel a figyelmet, hogy a továbblépési lehetőséget lenne fontos biztosítani. Utóbbi esetében a képzéseken való részvétel és az azt követô munkavállalás támogatása jelent meg igényként, s ezen belül is a helyben történő munkavállalás biztosítása, amely pillanatnyilag túlmutat a település és az ott élő foglalkoztatói kör (jellemzően kisvállalkozások működnek a településen) lehetőségein.

\section{Célcsoporti vélemények}

A kutatás másik egysége a programmal elért célcsoporttagok véleményét mérte fel. A megkérdezés a legrosszabb helyzetben lévő szegregátum, az Apáti telep lakosságára fókuszált. Az adatgyújtés strukturált interjú alkalmazásával történt, 2019. őszén kerültek felvételre. Az interjúk során 8 fővel készült interjú, amely a területen található háztartások kb. 25\%-a volt. Az interjúkészítés jellemzően 
nem csak az alany, hanem a családtagok jelenlétében történt, így a minta nagyobbnak tekinthető, hiszen egy családból többen is részt vesznek a programban. A válaszadók többsége rendelkezett információkkal a programról, tudták, hogy másfél éve fut a program és azt is, hogy ez a romák megsegítését szolgálja.

A megvalósítói háttérrel kapcsolatban, nevezetesen, hogy kik szervezik és bonyolítják a programot, megoszlottak a vélemények. Négy esetben az önkormányzatot nevezték meg a program lebonyolítójának, míg egy alany a roma nemzetiségi önkormányzatot, két válaszadó a roma nemzetiségi önkormányzatot és a települési önkormányzatot nevesítette megvalósítóként, míg egy fó nem ismerte a megvalósítói hátteret. A program megvalósítását a nevezett szervezeteken túl még egy civil szervezet segíti, amely nem a településen található, így a velük való kapcsolat korlátozottabb, rendszerint a különböző képzési programokat biztosítják a célcsoport számára, jelenlétük csupán időszakos a célcsoport életében, valamint az általuk szervezett programelemek is a projekt munkatársainak segítségével valósul meg, így közvetlen kapcsolat nem alakult ki a harmadik szervezettel.

Az egyéni fejlesztési folyamat az egyéni segítés mellett, különböző programelemeken keresztül valósul meg. Ezek közül bizonyos elemek, mint például a felnőttképzések, a munkavállalási kompetenciákat, míg mások, például a különböző klubfoglalkozások a szociális, vagy anyanyelvi kompetenciákat fejlesztik. A programkínálatból a válaszadók jellemzően azokat a társas együttlétet biztosító programelemeket emelték ki, amelyek túlmutatnak a családok anyagi lehetőségein. Ide sorolhatók a különböző kirándulások, közművelődési intézmények látogatása, egyéb kulturális tevékenységek, amelyek az informális tanulás lehetőségét biztosították a résztvevőknek. A gyerekek számára biztosított nyári táborok, kirándulások szintén népszerúek voltak, ezek ugyancsak olyan tevékenységek voltak, amelyeket a szülők nem tudtak biztosítani gyermekeik számára.

A közösségi programok a településen kerültek megrendezésre, ezek között családi napok, sportnapok szervezése történt meg, ezek olyan típusú programok voltak, ahol a közösség együtt vett részt a tevékenységekben, ezen túlmenően a főzőklubot említették meg néhányan.

Az Apáti telepről többen részt vettek a felnőttképzéseken is, a célcsoportban felismerték annak fontosságát, hogy a munkavállalást nagyban segítheti a megszerzett végzettség, ezek között volt olyan, amely tréning formájában valamely kompetenciát fejlesztette, de volt olyan is, amely OKJ-s végzettséget adott a résztvevőknek. $\mathrm{E}$ körbe sorolhatóak a kályhás, az óvodai dajka, valamint a targoncás képzések. Ezek a szakmák biztosították az elhelyezkedés lehetőségét is, amely néhány esetben meg is történt. Az Apáti telepen élők számára is alapvető foglalkoztatási forma a helyben elérhető közfoglalkoztatás, amely biztosnak tekinthető bevételt jelent. Bár ez a forma alacsonyabb jövedelmet jelent, a munkával töltött idô minimalizálható, valamint nem terhelik a munkavállalás egyéb költségei, mint például az útiköltség, étkezés költségei. Néhányan úgy terveznek, hogy az időszakos közfoglalkoztatás utáni időszakban helyezkednek el, s többen gondolkodtak úgy, hogy a közfoglalkoztatás mellett lehetőség nyilik alkalmi munkavállalásra is, így kiegészíthetô a családi bevétel.

Az integrációs program során 35 típusú programelem valósult meg, így a részvétel nem lehet teljes. A programelemek az egyéni fejlesztés részét képezik, hiszen a szabadidős tevékenységek mindegyike lehetőséget ad a kompetenciafejlesztésre, azokat felkészült szakemberek tartották meg. Az interjú során megemlített programok azonban arról árulkodnak, hogy a célcsoporti aktivitás nagyobb, mint ahogyan azt a szociális munkások percepcionálták.

A roma közösségen belüli kapcsolatokról többen úgy vélekedtek, hogy nem változott a településen élő romákkal a kapcsolatuk. A településen négy 
szegregátuma közül, az Apáti telep körülményei a legkedvezőtlenebbek, sok esetben a településen élő romák és nem romák egyaránt pejoratív jelzőkkel illetik az itt élóket, amelyet maguk is sokszor átélnek, s ennek okán kirekesztettnek érzik magukat. A megkérdezettek közül csupán egy fő nyilatkozta azt, hogy javult a viszonya a településen éló romákkal, amely oka, úgy gondolja az, hogy többet találkoznak a faluban élô romákkal is. A közösségi integráció megteremtését támogatja a programelemek megvalósítási színhelyéül szolgáló közösségi ház, amelyet a településen élő romák és nem romák egyaránt igénybe vehetnek, ez a település integrált részén, a központban található.

A településen élő nem romákkal való viszonyt kérdezve szintén azt említette a válaszadók többsége, hogy nem változott, míg két alany válaszolta azt, hogy javult, ennek okaként szintén a gyakoribb találkozásokat említették. A válaszok - bár nem reprezentatív a minta - azt a szociálpszichológiai téltelt látszanak alátámasztani, amely szerint a személyes találkozások elósegítik, hogy az emberre ne egy csoport tagjaként, hanem egyénként tekintsenek, s ez a viszony megváltoztatja a korábbi képet, véleményt az adott személyról (Mackie, Smith, 2004). Ennek alapján úgy tûnik, hogy közös együttlétek, a közös programok szervezése ezt a megismerési folyamatot a késóbbiekben is támogathatja. A szociális munkások jelenléte ezekben tovább erősítheti a csoportközi konfliktusok csökkentését, valamint a segítő-kliens viszony javításához is hozzájárulhat. A találkozások fontosságát a helyi aktivitás oldaláról vizsgálva szintén kiemelhetô, hogy az interjúalanyok úgy érezték, hogy a közösség összetartásában is van változás. A több találkozás kevesebb konfliktust eredményezett, aktívabb kapcsolatok alakulnak ki a projektben résztvevőkkel, amely több beszélgetést eredményezett. A program során a helyi közösség aktivizálása szintén fontos célkitűzés volt, ennek során a programokon résztvevők bekapcsolódtak a következő program tervezésébe, elmondhatták elképzeléseiket, amelyekből amit reálisan lehetett, be is építettek a később megvalósított programokba. Az együttmúködések, a résztvevők aktivizálásának kezdetét jelzi az is, hogy a környezetet érintő ügyekről a családtagok mellett a program munkatársaival is megosztják gondolataikat a megkérdezettek, csupán ketten válaszolták azt, hogy nem szoktak beszélni senkivel sem erről.

$\mathrm{Az}$ interjúalanyok percepcióját lakókörnyezetükkel kapcsolatban egy önálló kérdéscsoport mentén vizsgáltuk. Ezek egy része olyan objektívan vizsgálható kérdés, amelyet a KSH adatai is alátámasztanak. A megkérdezettek deprivációs percepciója illeszkedik a KSH által meghatározott jellemzőkhöz, alanyaink az interjúk során a csatorna és vízvezeték hiányát, a gáz, a járda hiányát emelték ki. E mellett azonban egyértelmúen megfogalmazták, hogy egy elszigetelt településrészen élnek, ahol sok konfliktus alakul ki az ott élők között, valamint, hogy jellemzően szegények laknak a területen, és megemlítették a kedvezőtlen körülményeket is. Csupán két esetben tettek arra vonatkozó utalást, hogy békés, csendes környék, ahol élnek. A válaszadók tehát környezetüket, a fizikai körülményeket reálisan látják.

A szociális munkával kapcsolatos kérdések kapcsán az rajzolódott ki, hogy a projekt szakemberei jellemzően havonta többször is felkeresik őket, csupán egy esetben jelezte az egyik alany, hogy nem jár hozzá szociális munkás és szintén egy, aki úgy itélte meg, hogy havonta egy alkalommal keresi fel a szociális munkás. Ennek kapcsán megkérdeztük, hogy kihez fordulnak, ha valamilyen problémájuk van. A válaszadók döntő többsége úgy válaszolt, hogy a polgármesterhez fordul, ha szociális problémája van, s csupán egy esetben említették meg, hogy a szociális munkáshoz. Ezt azzal magyarázták, hogy a polgármester tud nekik azonnali segítséget adni, néhány ezer forintos támogatást, vagy egyéb szükséges segítséget. Ez a jelenség jól jelzi a kistelepülések sajátosságait, amikor az ellátórendszeren belüli azonnali segítség- 
nyújtás nem megoldott, így a pénzeszközzel is rendelkező polgármester vagy jegyző lehet a segítségnyújtás útja.

Az interjúk során felsorolásban kértük, nevezzék meg, hogy szerintük milyen szolgáltatásokra lenne szüksége a területen élőknek. A válaszokat összesítve az alábbi összegzés adódott, az emlitések csökkenő sorrendjében:

- lakáskörülmények javítása (8 említés)

- egészségügyi szűrések (7 említés)

- személyes segítő a napi ügyintézésben (7 említés)

- táborok a gyerekeknek (7 említés)

- kirándulások (7 említés)

- munkavállalás segítése (6 említés)

- képzések felnőtteknek (5 említés)

- korrepetálás (5 említés)

- közösségi programok (4 említés)

- gyerekeknek szóló rendezvények (4 említés)

- mosási lehetőség (3 említés)

- adósságrendezés ( 3 említés)

- háztartási ismeretek (2 említés)

- közös bulik (1 említés)

- tisztálkodási lehetőség (1 említés)

- kerítés építése (1 említés)

- idősellátás (1 említés)

A szükséges szolgáltatások említése a megkérdezettek körében két fontos dologra hívja fel a figyelmet. Az egyik, hogy a program tervezése valós igényfelmérésen alapult, ezt támasztják alá azok a „humán típusú” szolgáltatások, amelyeket az alanyok említettek, felsoroltak. A másik, az infrastrukturális beavatkozás fontossága, amely komoly célcsoporti elvárást is jelez. Ez azonban potenciális konfliktusforrás is a projekten belül, hiszen a humán fejlesztési tartalmakban nem jelenhetnek meg infrastrukturális elemek, ezekben azok a fejlesztési dimenziók szerepelhetnek, amelyek formális, nonformális és informális keretek között átadhatóak a célcsoporttagok számára, valamint a szociális munka, mint egyéni támogatási mód biztosítható.

A lakhatási körülmények javítása azonban reális igény, amelyre a környezettel kapcsolatos célcsoporti percepciók is rámutattak. A probléma ott jelentkezik, hogy bár a lakhatási körülmények javítására külön forrás áll rendel-kezésre, amelyből lakások felújitása és új szociális bérlakások építése valósul meg, azonban a források nagysága kb. 3035 ember, vagyis 8-10 család részére teszi elérhetôvé ezt a típusú szolgáltatást. Az uniós szabályozásnak megfelelően csak az önkormányzati tulajdonú ingatlanokon lehet fejlesztéseket megvalósítani, amely kódolja a későbbi konfliktust a programban. Ez a tény a szociális munkásokra és a projektben résztvevő mediátor számára újabb feladatokat jelent majd, amely eredményessége e sorok írásakor még nem prognosztizálható.

A csoportközi konfliktusokra vonatkozóan az interjú során megkérdeztük, hogy mit gondolnak azokról a romákról, akik a település más részein élnek. A válaszok a jobb körülményeket említették a máshol élőkkel kapcsolatban, azonban egy fontos részlet is kirajzolódott, amely a saját státuszukra vonatkozott. Az interjúalanyok öt esetben említették azt, hogy a faluban élő romák lenézik az itt élőket, valamint azt, hogy nincs kapcsolatuk velük. Ez a két tény azt mutatja, hogy a hasonló sorban élő romák esetében is van különbségtétel, amelyet elsősorban a térbeli szegregáció, a településszövettôl való távolság indukál, még akkor is, ha egyébként rokoni kapcsolat is füzi az itt élőket a falusi romákhoz. A szegregáció okozta kedvezôtlen helyzet, a halmozódott hátrányok ́́gy a kapcsolati tőkére is hatással vannak. A kirekesztést erősíti az is, hogy bizonyos szolgáltatók - az interjúalanyok szerint - azért nem biztosítanak szolgáltatást számukra, mert a lakcímük az Apáti telep és ez már a cigánytelepet vetíti a szolgáltatók elé.

A helyi problémák egy része a korábban említett infrastrukturális ellátottságból ered. Az interjú 
során egyéb problémákra is rákérdeztünk, az interjúkban elmondott problémákból az alábbi tipizálás állítható fel:

- fiatalok drogfogyasztása (8 említés)

- a fiataloknak nehéz a lakáshoz jutás (7 említés)

- nem segítik a szegényeket (6 említés)

- rossz a közbiztonság (5 említés)

- rossz az egészségügyi ellátórendszer (5 említés)

- nincs munkalehetőség (4 említés)

- rossz az oktatás (4 említés)

- diszkriminálják a romákat (3 említés)

- konfliktusok vannak romák és nem romák között (3 említés)

- rossz az óvoda (2 említés)

- nincs éjszakai orvosi ügyelet, nincs gyermekorvos (1-1 említés)

A nem infrastrukturális problémák között kiemelkedő helyen szerepel a drogfogyasztás, azonban érdekes, hogy a projekt szolgáltatásai között egyébként szereplő drogprevenciós foglalkozásokat nem említették ismert programelemként. A lakáshoz jutás problémája a fiatalok körében szintén majdnem minden válaszadónál előkerült, amely csak erôsíti a korábban jelzett konfliktusos helyzet kialakulását. A felsorolt problémák zöme az ismert problémák köré szerveződött, ezek mind az igényfelmérésből, mind a szakirodalomból ismertek. Az utolsóként említett orvosi ügyelet és gyermekorvosi ellátás hiánya pedig nem településspecifikus, ez a kistelepülések zömét sújtja a térségben.

A problémákat, a programból fakadó lehetôségeket a családra vonatkoztatva is megkérdeztük, amely az interjút egészítette ki zárt kérdések formájában. A megadott állításokat kellett értékelni egytől - ötig terjedő skálán, valamint adtunk önálló válaszra is lehetőséget. Az értékelés során a 2,5 alatti érték jelenti az elutasítást, vagyis nem jellemző, míg az e fölötti jellemzó a családra. Az 1. ábra foglalja össze a kapott eredményeket.

\section{1. ábra - A családdal kapcsolatos problémák, jellemzőo megitélése (saját szerkesztés)}

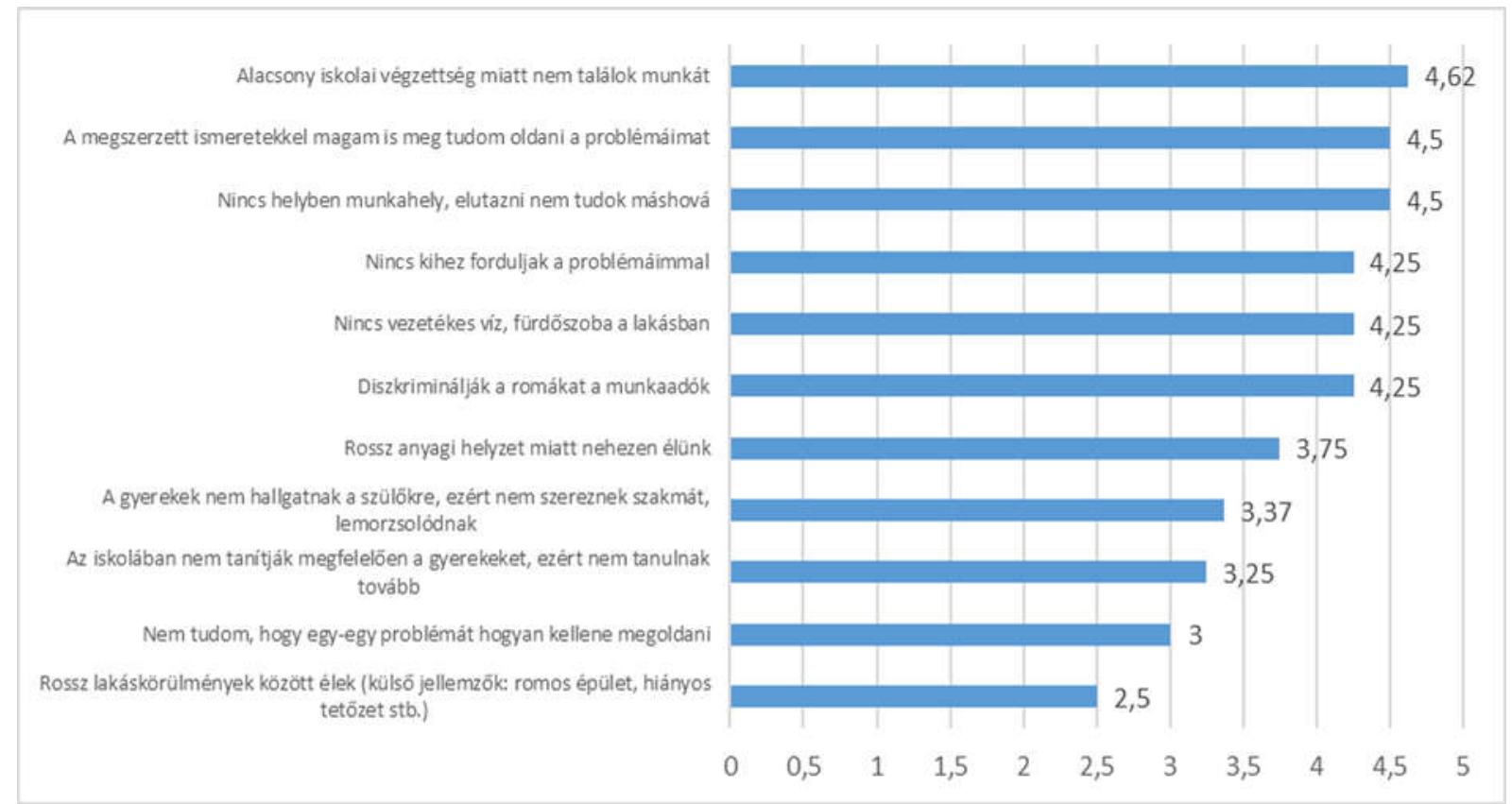


A válaszadók a problémáik között az alacsony iskolai végzettséget $(4,62)$, a helyben lévô munkahelyek hiányát, valamint ehhez kapcsolódóan az alacsony munkavállalási mobilitást $(4,5)$, a segítség hiányát $(4,25)$, a romákkal szembeni diszkriminációt $(4,25)$, a rossz anyagi helyzetet $(3,75)$ tartják magukra nézve releváns megállapításoknak. Az infrastrukturális hiányosságok itt is megjelennek jellemzőként, a vezetékes víz és fürdőszoba hiánya magas értéket kapott $(4,25)$, azonban ennek hiányát még nem tekintik automatikusan rossz lakáskörülményeknek, hiszen azt lényegesen alacsonyabbra értékelték $(2,5)$ a válaszadók. A gyerekek jövőjével kapcsolatban kettős problémát jeleznek az értékek. Az egyik a gyerekek magatartása, a szülői tekintély hiánya lehet, hiszen ezt a jellemzőt magasabbra értékelték (3,37), míg ehhez kapcsolódva az iskola szerepét, az oktatási minőség alacsony voltát jelzik, mint a gyerekek boldo- gulásának egyik hátráltatóját (3,25). A problémák megoldására vonatkozóan szintén kettősség figyelhető meg, egyrészről magasan értékelték az önálló problémamegoldáshoz meglévő kompetenciákat $(4,5)$, de e mellett némi bizonytalanság is megjelenik, amely szerint nem tudják, miként oldják meg problémáikat (3). A kijelentések értékelése azt is jelzi, hogy a válaszadók helyzetüket inkább reálisan látják, s a szociális munka szempontjából nem elhanyagolható az a tény, hogy a problémamegoldáshoz szükséges kompetenciák birtokában érzik magukat a válaszadók.

Ezt a szemléletet tükrözi a következő kérdésre adott válaszok értéke is, amely során a problémák megoldásához szükséges partnereket lehetet értékelni. Ennek során egyértelműen körvonalazódott, hogy a problémák megoldásának kulcsát elsősorban magukban látják a válaszadók, ahogyan az a 2. ábra eredményeirôl leolvasható.

2. ábra. A problémamegoldás szereplöi (saját szerkesz̨tés)

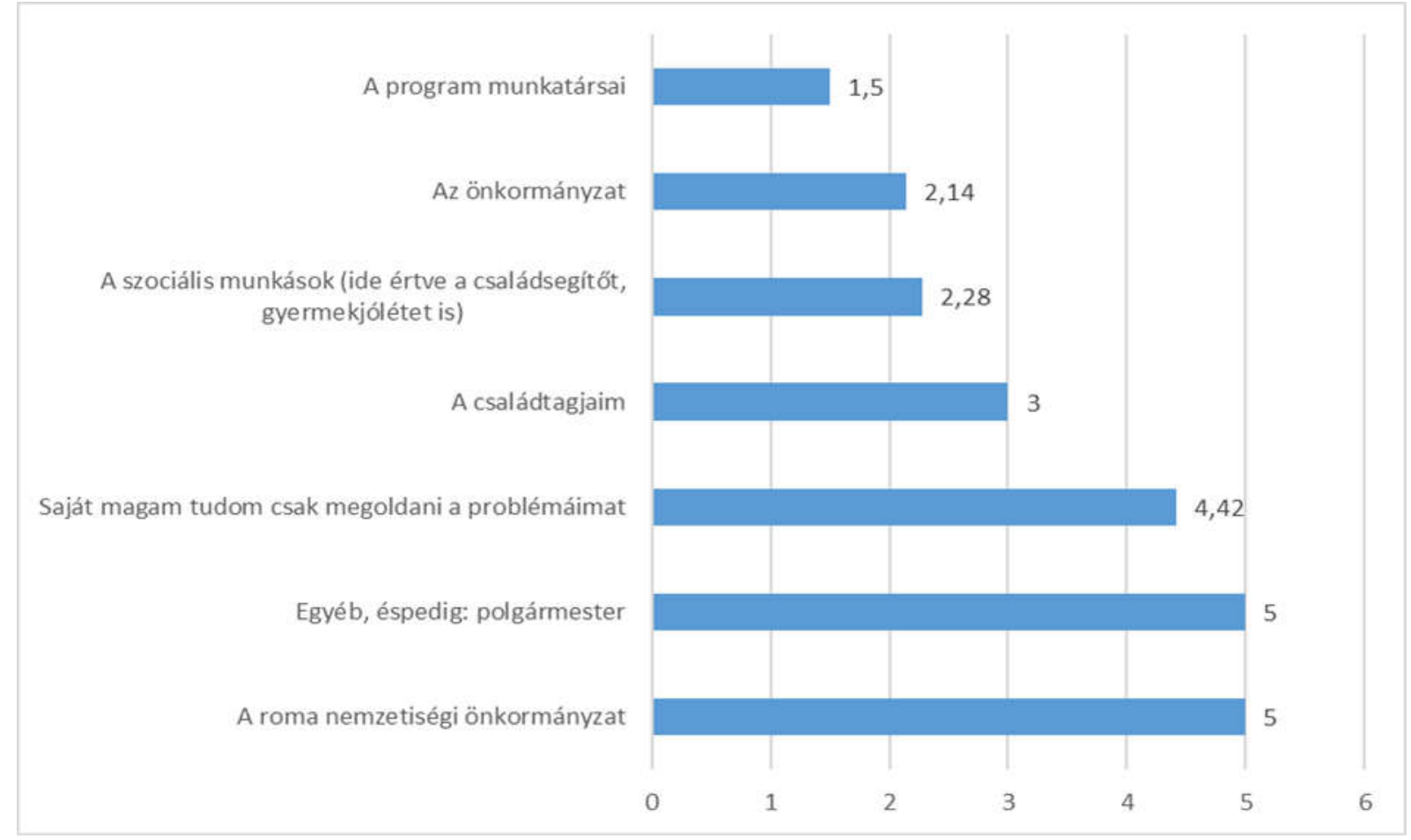


A válaszok között sajátos szórás alakult ki, hiszen a polgármester mindenhatósága és a roma nemzetiségi önkormányzat szerepe kapta a legmagasabb pontokat, de az eredmények torzítanak, mert a két válaszlehetőségre csupán egy-egy válasz érkezett. A további értékelések tanulságosan alakulnak, hiszen a program munkatársai alacsony értéket kaptak $(1,5)$, amely a válaszadók realitásérzékének is betudhatunk, hiszen a problémák megoldásában a közösség- és programszervező munkatársak valóban keveset tudnak segíteni. Úgy tűnik, hogy az önkormányzattól sem várnak komolyabb segítséget $(2,14)$, és úgy vélik, hogy a szociális munkások sem tudnak segíteni a problémák megoldásában $(2,28)$, amely a program szempontjából szükségessé teszi a szociális munka gyakorlatának átgondolását. A megoldás egyértelmúen a család (3) és a saját kompetenciák területére fókuszál $(4,42)$, vagyis a válaszadók úgy gondolják, hogy a problémák akkor oldódnak meg, ha önmaguk veszik kézbe ezek kezelését.

A program célcsoporti értékelése hasonló módszerrel készült el. A válaszlehetôségek a program eredményeivel kapcsolatos várható eredményeket tartalmazta, amelyek túlmutatnak a megszámlálható indikátorokon, a benyomásokat, a fôbb programelemekről való gondolkodást igyekeztek feltérképezni.

A következő 3. ábrán az ezzel kapcsolatos megítélést foglaltuk össze.

3. ábra. A programmal keapcsolatos megitélés (saját szerkesztés)

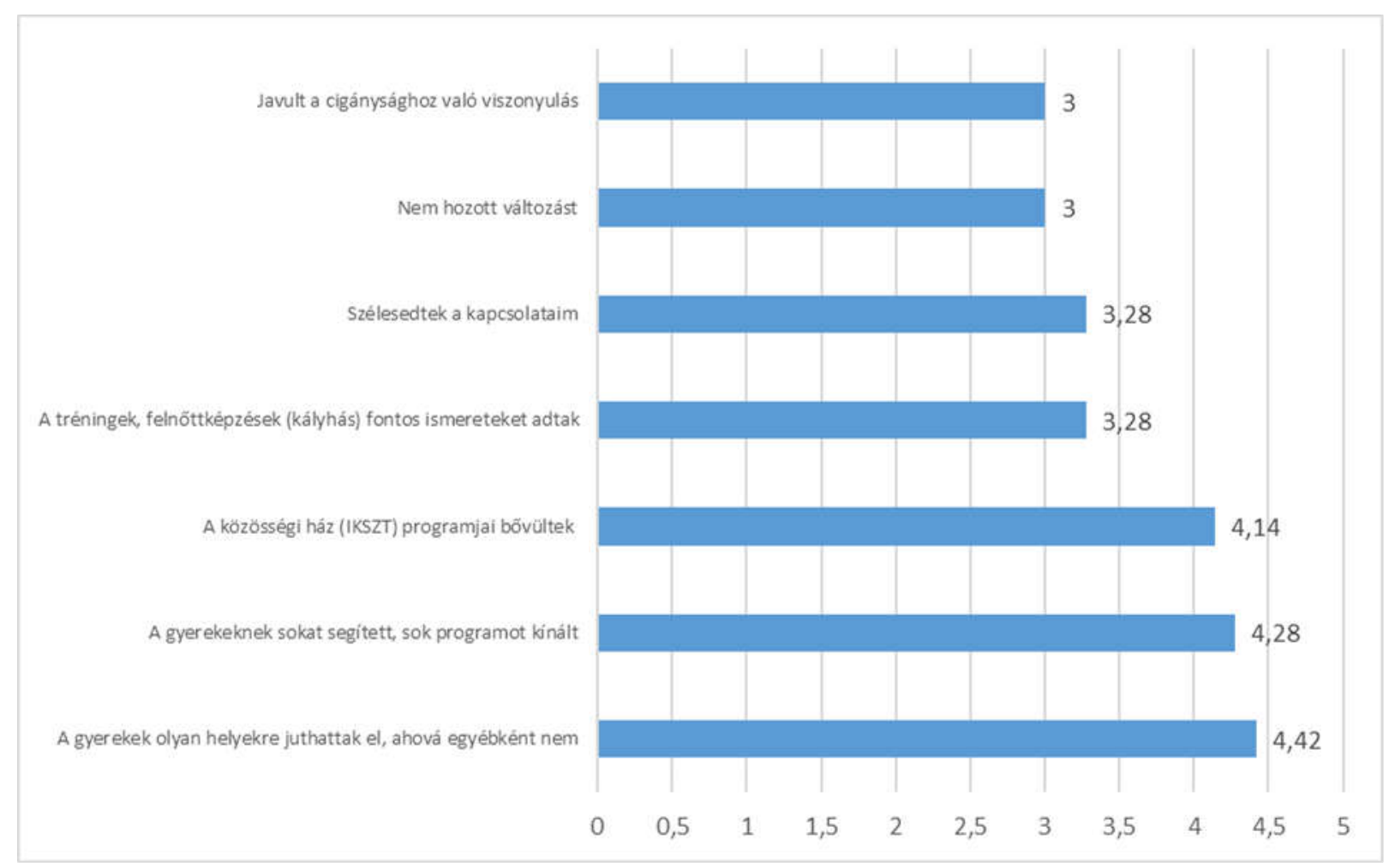


A deszegregációs programok sajátja lenne, hogy a roma - nem roma közösségek közötti kapcsolatok javuljanak, a másik megismerése megtörténjen, a sztereotípiák és előitéletek csökkenjenek. A válaszokból az derült ki, hogy ennek az útnak a projekt még nem ért a végére, hiszen a cigánysághoz való viszonyulás viszonylag alacsony értéket mutat (3), amely kismértékú változást feltételez. Ezt a kismértékủ változást támasztja alá az is, hogy szintén ilyen értékkel (3) szerepel az az állítás is, amely szerint nem hozott változást a projekt. Az állításokat kontrolkérdésként is értelmezhetjük, így látható, hogy kismértékben ugyan, de javultak a kapcsolatok $(3,28)$ és az egyik legnagyobb problémának tartott területen, az alacsony iskolai végzettség javításában is sikerült elóbbre lépni (3,28). A közösségi rendezvények helyszínéül szolgáló tér szerepe már magasabb értékelést kapott $(4,14)$, valamint az itt lévő programok is szélesedtek, $s$ ennek a ténynek a válaszadók tudatában is vannak, különösen igaz ez a gyerekek esetében, ezzel kapcsolatban úgy vélik, hogy számura sok programot kínál $(4,28)$ a közösségi ház. Ugyancsak visszaigazolják az értékelések, hogy több olyan programelemet szerveztek meg, amelyhez eddig a gyerekek nem fértek hozzá $(4,42)$. Az interjú elején ide sorolták a kirándulásokat, táborokat az interjúalanyok.

Összefoglalva elmondható, hogy a szolgáltatások bővitése a célcsoport körében, s ezen belül is a gyermekek körében sikeresnek tekinthető.

A kutatási eredményeket áttekintve azt láthattuk, hogy a program lényegi elemét adó szociális munka problémákkal terhelt. A szociális munkások feladatvégzése komoly idôbeli korlátok közé szorult, amelyet alapvetôen a szakemberek hiányának tulajdoníthatunk. Ennek alapján az elvárt feladatok, a magas, 30 fős kliensi kör, valamint a nagyfokú adminisztráció terheli a rendszert, amely nehezíti a kliensekkel bizalmi, partneri viszony kiépítését. Vélhetôen ezt a folyamatot erôsíti az is, hogy a megszokott hierarchikus viszonyból a szociális munkások egy része nem tud vagy akar kilépni annak ellenére sem, hogy erre vonatkozó speciális képzésen vettek részt. A célcsoporttal kapcsolatos vélemények - megítélésem szerint - ebból fakadóan fogalmazódnak meg, esetenként a saját kompetenciahiányokat vetítve a kliensekre. Ezzel szemben a célcsoporti interjúkból és az egyes részkérdésekre vonatkozó felmérésekből a célcsoport deprivációs percepciója helytálló, pontosan megfogalmazták a hiányosságaikat, valamint azt is, hogy sorsuk alakításában elsődleges szerepük nekik van. Ez a tény inkoherenciát mutat a szociális munkások egy csoportjának véleményével, amelyre pedig erőforrásként lehetne tekinteni az egyéni fejlesztések során, s ezzel hatékonyabbá tenni a célzott fejlesztési programot. A programmal kapcsolatos megitélések azonban azt mutatják, hogy a felmérés idején a fejlesztési célok éreztették hatásukat, bár némi szkepticizmus is levonható a véleményekből, mert élethelyzetük javulását nem ettől a programtól várják, hanem saját maguk kívánják megoldani. Szintén pozitívum volt a fejlesztéssel kapcsolatban, hogy úgy túnik, voltak olyan szakmai tartalmak, amelyek az önálló problémamegoldáshoz hozzájárultak.

A fent ismertetett telepes program egy a felzárkózást segítő programok közül. Komplexitása, több terület egyidejű fejlesztésének a szükségessége azonban különösen fontossá teszi, hogy a szociális munkát végző szakemberek a sok esetben 30 fős kliensi körhöz igazodjanak és főállású munkatársként lássák el feladataikat. Szakmai tevékenységük során indokolt a szociálpedagógia, szociális munka modern szemléletét alkalmazni, és a kliensek gondolkodását kiaknázva a problémamegoldó képességüket erősíteni. A programok további feladata lehet egy-egy lokalitáson belül a különböző csoportok együttmúködésének javitása. Erre vonatkozóan a program lehetôséget biztosít, és ahogyan látható volt, már félidei vizsgálat esetén is tapasztalható elmozdulás ezen a téren. A szegregátumok helyzetén az ilyen típusú 
programokkal áttörést nehéz elérni, a fenntarthatósági szempontok mérlegelése mellett célszerű az ágazatközi együttműködések helyi és térségi szintű gyakorlatát létrehozni.

\section{Irodalom}

Babbie, E. (1996). A társadalomtudományi kutatás gyakorlata. Budapest: Balassi Kiadó.

Csoba, J., Prókai, O. (2011): Esetkönyv. Példatár az. egyéni esetke zelésének gyakorlatához. Debrecen: Szociotéka

Domokos, V. (2010). Szegény- és cigánytelepek, városi szegregátumok területi elhelyezkedésének és infrastrukturális állapotának elemzése különbözó" (közoktatási, egészségügyi, településfejlesztési) adatforrások egybevetésével. Budapest: KOR IH, LHH Fejlesztési Programiroda

Európa 2020 (2010). EURÓPA 2020 Az intelligens, fenntartható és inkluそiviv növekedés stratégiája Forrás: https://ec.europa.eu/eu2020/pdf/1_HU_ACT part1 v1.pdf Letöltés ideje:2021.02.10.

Farkas, Zs. (2018). Búcsú a cigányteleptől? Telepfelszámolási programok integrációs hatásai és nem szándékolt következményei a rendszerváltás előtt és 2005-2010 között. Esély 29/1. 42-66.

Hajnáczky, T. (2015). Borsod-Abaúj-Zemplén megyei cigányság helyzete a szocialista korszak-ban a levéltári források tükrében. In: Csengeri, P., Tóth, . (szerk.): A Herman Ottó Múzeum Évkönyve LIV. Miskolc, 483-495.

Jelenlét (é.n.): A Jelenlét program képzési segédanyagai. A segédanyagokat az EFOP-1.6.1VEKOP/16-2016-00001 Felzárkózási együttmúködések támogatása címú projekt keretein belül megvalósult szociális munkás képzéshez kapcso-lódóan.

Herpainé Márkus, Á. (2011). Fenntartható fejlődés és szociális munka - öko-szociális munka. In Jász, K. (szerk.): Szociális munka a fenntartható fejlödésért. Szekszárd: PTE IGYK, 47-63.

Hilscher, R. (1989). A settlement-mozgalom. Esély I./1. 55-64.

Jász, K. (2011). Szociális munka fenntartható alapokon. In Jász, K. (szerk.). Szociális munka a fenntartható fejlödésert. Szekszárd: PTE IGYK, 2946.

Kállai, E., Törzsök, E. (szerk.) (2006). Átszervezések kora. Cigánynak lenni Magyarországon. Jelentés 20022006. Budapest: Európai Összehasonlító Kisebbségkutatások Közalapítvány

Közösségi Beavatkozási Terv (2017): Pocsaji Integrációs Program. Közösségi Beavatkozási Terv. Kézirat.

Kemény, I., Janky, B. Lengyel, G. (2004). A magyarországi cigányság 1971-2003. Budapest: Gondolat Kiadó - MTA ENKI

Kocsis, P. Cs. (2014). Menni vagy maradni? Telepes programok megvalósitóinak mühelykenferenciája. Jászfényszaru 2013. november 28. Forrás: http://www.baks.hu/ajovonekdolgozunk/wpcontent/uploads/2014/02/Menni-vagymaradni kesz.pdf Letöltés ideje: 2020.12.20.

Kocsis, P. Cs. (2019). A magyarországi roma integrációs törekvések történeti aspektusai Budapesten. In Biczó, G. (szerk.): Így kutatunk mi. A Lippai Balázs Roma Szakkollégium romológiai tanulmánygyüjteménye. Debrecen: Didakt Kft., 5168.

KSH (2011): Pocsaj település népszámlálási adatai. Forrás: $\quad$ http://www.ksh.hu/nepszamlalas/ tablak teruleti 09 Letöltés ideje: 2021.02.12.

L. Ritók, N. (2017): Láthatatlan Magyaroroszág. Budapest: Tea Kiadó

Mackie, D.M., Smith, E.R. (2004): Szociálpszichológia. Budapest: Osiris.

Majtényi, B., Majtényi, Gy. (2012). A cigánykérdés Magyarországon 1945-2010. Budapest: Libri Kiadó. 
Mezey, B. (szerk.) (1986). A magyarországi cigánykérdés dokumentumokban 1422-1985. Budapest: Kossuth Könyvkiadó.

MNTFS 2030 (2020). Magyar Nemzeti Társadalmi Felzárkózási Stratégia 2030. Forrás: http://romagov.hu/wpcontent/uploads/2020/12/MNTFS2030_1201tervezet.pdf letöltés ideje: 2021.02.12.

MNTFS II (2014). Magyar Nemzeti Felzárkózási Stratégia II. Tartósan rászorulók - szegény családban élō gyermekek - romák (2011-2020) Forrás: https://www.kormany.hu/download/1/9c/200 00/Magyar $\% 20$ NTFS $\% 20 \Pi 1 \% 20 \quad 2 \% 20$ mell $\% 2$ 0 NTFS\%20II.pdf Letöltés ideje: 2019.10.07.

Net1: Városfejlesztési kézikönyv. Második, javított kiadás. Nemzeti Fejlesztési és Gazdasági Minisztérium Területfejlesztésért és Épitésügyért Felelős Szakállamtitkárság, Budapest. Forrás: http://www.terport.hu/webfm_send/3989 Letöltés ideje: 2021.02.21.

Net2: TÁMOP-5.3.6-11/1 Komplex telep-program (komplex humán szolgáltatás hozzáférés biztosítása) Pályázati felhívás, Forrás: https://www.palyazat.gov.hu/doc/3367\# Letöltés ideje: 2019.10.12.

Net3: EFOP-1.6.2-16 Szegregált élethelyzetek felszámolása komplex programokkal (ESZA) Forrás: https://www.palyazat.gov.hu/efop-16216-szegreglt-lethelyzetek-felszmolsa-komplexprogramokkal-esza\# Letöltés ideje:2020.10.12.
Net4: EFOP-2.4.1 Szegregált élethelyzetek felszámolása komplex programokkal (ERFA) Forrás: https://www.palyazat.gov.hu/efop-241szegreglt-lethelyzetek-felszmolsa-komplexprogramokkal-erfa\# Letöltés ideje:2020.10.12.

Net5: A szociális munka etikai kódexe. Forrás: http://3sz.hu/sites/default/files/Etikai.pdf Letöltés ideje: 2020.10.10.

NTFS I. (2011): Nemzeti Társadalmi Felzárkózási Stratégia - mélyszegénység, gyermekszegénység, romák 2011-2020.

Forrás:

http://romagov.hu/download/nemzetitarsadalmi-felzarkozasi-strategia/ Letöltés ideje: 2021.03.07.

Petrovácz, R., Somogyi, E. \& Teller N. (2010). Telepeken és telepszerü lakókörnyezetben élök integrációs programjában értékelése. Budapest: Városkutatás Kft. (kézirat)

RIÉP (2007): 68/2007 OGY határozat a Roma Integráció Évtizede Program Stratégiai Tervről. Forrás:

https://mkogy.jogtar.hu/getpdf?docid $=\mathrm{a} 07 \mathrm{~h} 00$ 68.OGY\&printTitle $=68 / 2007 .+\% 28 \mathrm{VI} .+28 . \%$ $29+\mathrm{OGY}+$ hat $\% \mathrm{C} 3 \% \mathrm{~A} 1$ rozat $\&$ targetdate $=$ fffff ff4\&referer=lawsandresolutions Letöltés ideje: 2021.03.14. 